\title{
Direct aortic approach for TAVl: a single centre experience
}

\author{
H Amrane ${ }^{1 *}$, F Porta $^{1}$, S Head ${ }^{2}$, A van Boven ${ }^{3}$, A Kappetein $^{1}$ \\ From 23rd World Congress of the World Society of Cardio-Thoracic Surgeons \\ Split, Croatia. 12-15 September 2013
}

\section{Background}

Direct aortic approach is an attractive alternative technique for transcatheter aortic valve implantation in challenging patients. We report a brief description of this surgical technique and the short term results of our first series.

\section{Methods}

Our group consisted of 35 inoperable patients presenting aortic valve disease unsuitable for transfemoral valve implantation due to extreme peripheral vessel disease. Data were prospectively collected and retrospectively analysed. Using an upper-J mini sternotomy access to the third intercostal space the ascending aorta was exposed. After placing two purse-strings on the ascending aorta at least $7 \mathrm{~cm}$ above annulus, the delivery system was inserted and advanced under fluoroscopy to the optimal position and the valve was deployed.

\section{Results}

Mean age of the patients was 77 years old, mean logistic EuroScore $27 \%$. Evaluation of the results in these 35 patients treated with the Direct Aortic Approach was made according to the Valve Academic Research Consortium consensus criteria. These include device success endpoints and combined safety endpoints at 30 days. Device success was achieved in $94 \%$ of the patients. All cause mortality was $9 \%$ at 30 days. One major stroke (3\%) and one life threatening bleeding occurred (3\%). Pacemaker implantation rate was 9\%. The evaluation of the combined efficacy endpoints at 1 year has not been completed yet.

\footnotetext{
* Correspondence: hafid.amrane@znb.nl

'Department of Cardiothoracic Surgery, Medisch Centrum Leeuwarden, Leeuwarden, the Netherlands

Full list of author information is available at the end of the article
}

\section{Conclusion}

These results represent the initial experience of a single centre after adopting the direct aortic approach for TAVI as alternative to the transfemoral route. It is less invasive, fast and safe and can be performed with acceptable mortality and morbidity in high risk patients.

Due to the short distance between access point and aortic annulus the positioning of the valve is believed to be more accurate than alternative access route like the transfemoral approach.

\section{Authors' details}

${ }^{1}$ Department of Cardiothoracic Surgery, Medisch Centrum Leeuwarden, Leeuwarden, the Netherlands. 'Department of Cardiothoracic Surgery, Erasmus Medisch Centrum, Rotterdam, the Netherlands. ${ }^{3}$ Department of Cardiology, Medisch Centrum Leeuwarden, Leeuwarden, the Netherlands.

Published: 11 September 2013

doi:10.1186/1749-8090-8-S1-0316

Cite this article as: Amrane et al:: Direct aortic approach for TAVI: a single centre experience. Journal of Cardiothoracic Surgery 2013

8(Suppl 1):0316.

Submit your next manuscript to BioMed Central and take full advantage of:

- Convenient online submission

- Thorough peer review

- No space constraints or color figure charges

- Immediate publication on acceptance

- Inclusion in PubMed, CAS, Scopus and Google Scholar

- Research which is freely available for redistribution

\section{Biomed Central}

